\title{
4. 膵粘液性囊胞腫瘍の診断
}

$\begin{array}{llllllll}\text { 羽場 } & \text { 真 } & \text { 山雄 } & \text { 健次 } & \text { 外山 } & \text { 貴洋 } & \text { 飯田 } & \text { 章人 } \\ \text { 溝口 } & \text { 直人 } & \text { 大谷 } & \text { 宣人 }^{1)} & \text { 沢井 } & \text { 博純 } & \text { 桐山 } & \text { 諭和 } \\ \end{array}$

\section{索引用語：膵粘液性囊胞腫瘍（MCN） MCN全国調查 画像診断 襄胞液分析}

\section{はじめに}

膵粘液性豪胞腫瘍 (mucinous cystic neoplasm；MCN）は1978 年に Compagno ら ${ }^{1)}$ が初め て提唱した疾患であり, 比較的稀な腫瘍でありな がら，もう 1 つの粘液性膵腫瘍である膵管内乳頭 粘液性腫瘍（intraductal papillary mucinous neoplasm ; IPMN) の分枝型との対比の中で, その特 徵的な臨床像と病理像は広く知られてきている。 2007 年に日本膵臓学会は膵囊胞性病変に対する 4 つのワーキンググループを組織し, IPMN と $\mathrm{MCN}$ の種々の課題について検討した。 そのワー キンググループの 1 つである襄胞小委員会 MCN 予後調査研究チームにおいて,「卵巣様間質の存在 により厳密に定義された MCN の臨床病理学的検 討と長期予後について」の多施設共同, 後ろ向き 研究が害施され，2011年に英語版としてPancreas 誌2)に，また 2012 年には日本語版として本 誌3)に公表された。この研究(以下, 全国調査とす る）では, 全国 20 施設より外科的切除された $\mathrm{MCN}$ 確診/疑診例 171 例を集計した。 その全例を 膵臓病理が専門の 4 名の病理委員が鏡検・診断 し, 卵巣型間質を有する $\mathrm{MCN}$ 症例として 156 例 が抽出され, 臨床病理学的特徵, および長期予後 についての調査研究がなされた，本邦における卵 巣型間質を必須条件とした初めての全国規模の症

\footnotetext{
1) 成田記念病院消化器内科

2) 同外科

3) 同 病理診断科

4) 愛知県がんセンター中央病院消化器内科部
}

例集積調査であり, 詳細な結果報告によって $\mathrm{MCN}$ の特徵的な臨床像が明らかにされ, さらに 検討が必要な事項も浮かび上がってきた.

本稿では, 前述の全国調查を踏まえて MCN の 臨床病理学的特徴を概説し, 臨床診断, 特に術前 画像診断において重要と思われる事項について述 ベる.

MCN の臨床病理学的特徵（Table 1)

一全国調査の結果を踏まえて一

\section{MCN の臨床像}

$\mathrm{MCN}$ は膵外分泌性腫瘍の 2 5\% を占める比較 的稀な腫瘍で, 20 歳代から中年の女性の膵体尾部 に好発し ${ }^{4)}$, このことは発生学的に左原始生殖腺と 背側膵原器が胎生 $4 \sim 5$ 週には近接しており, $\mathrm{MCN}$ が迷入した異所性卵巣由来であることを説 明する根拠であるとされている5). 全国調査におい ても全 156 例中 153 例 (98.1\%) は女性であり， 155 例 $(99.4 \%)$ で膵体尾部に局在していた22.

臨床症状として MCN に特徵的なものは知られ ていないが, 輁胞内出血による腹痛や, 腫瘍径が 大きい場合は腹部腫瘤を主訴に受診する症例も存 在する. 全国調査では 138 例中 67 例 $(48.6 \%)$ が 有症状であった。 また, 他臓器癌との合併を $6.5 \%$ に，急性膵炎等の他の膵疾患の合併を $13.1 \%$ に認 めた。

2. MCN に特徵的な肉眼形態および病理像 (Fig. 1)

$\mathrm{MCN}$ は肉眼的に膵外方へ突出する単房から多 房性の楕円形もしくは球形の囊胞性腫瘍であり, 複数の囊胞を包括する共通の厚い線維性被膜を有 
Table 1 卵巣型間質を有する MCN の臨床病理学的特徵 (全国調査より) (文献 2 より引用, 一部改変)

\begin{tabular}{|c|c|}
\hline 総症例数 & 156 \\
\hline 年歯令（範囲） & $48.1 \pm 14.4$ 歳（19-84） \\
\hline 性別（男，女） & $3(1.9 \%), \quad 153(98.1 \%)$ \\
\hline 有症状例 & $48.6 \%(67 / 138)$ \\
\hline 他蔵器癌の合併 & $6.5 \%(10 / 154)$ \\
\hline 膵疾患の合併 & $13.1 \%(20 / 153)$ \\
\hline 急性膵炎 & 10 \\
\hline 糖尿病 & 7 \\
\hline 神経内分泌腫瘍 & 2 \\
\hline 高アミラーゼ血症 & 1 \\
\hline 病変部位（頭部，体尾部） & $1(0.6 \%), 155(99.4 \%)$ \\
\hline 病変の大きさ & $65.3 \pm 40.9 \mathrm{~mm} \quad(10-264)$ \\
\hline 主膵管との交通 & $18.1 \%(25 / 138)$ \\
\hline estrogen receptor (ER) 陽性 & $78.0 \% \quad(85 / 109)$ \\
\hline $\begin{array}{l}\text { progesterone receptor（PR）陽性 } \\
\text { 組織型 }\end{array}$ & $87.9 \% \quad(94 / 107)$ \\
\hline 腺腫 & $129(82.7 \%)$ \\
\hline 腺癌 & $27(17.3 \%)$ \\
\hline 非浸潤癌 & $21(13.4 \%)$ \\
\hline 微小浸潤癌 & $4(2.6 \%)$ \\
\hline 浸潤癌 & $2(1.3 \%)$ \\
\hline
\end{tabular}

する形態であることから “夏みかん様” ${ }^{6)}$ と形容さ れることが多い。 この特徵は, 異胞性膵腫瘍とし て MCNよりも高頻度に遭遇するIPMN と比較 するとわかりやすい. 分枝型 IPMN は分枝膵管が 粘液によって種々の程度に拡張するため, 隔壁を 伴った多房性囊胞がいわゆる“ブドウの房状”の 形態をとることが特徴であり, 外側に凸の襄胞で 共通の被膜を有さず各々の囊胞が隣接 (cyst by cyst）し, 主膵管との交通を認めることが多い。一 方, MCN は大小の震胞が共通被膜に覆われて 各々が交通せず独立 (independent cyst) し, かつ 共通の大きな囊胞の中に多数の囊胞を包含する形 態 (cyst in cyst) が特徵として認められる7). 囊胞 内部には腫瘍細胞から分泌された粘液が充満し, 時に出血や壊死物質を伴うことがある. 全国調査 ${ }^{2}$ では, 平均襄胞径は $65 \mathrm{~mm}$ で, $18.1 \%$ に主膵管と の交通がみられ，主膵管との交通を有さないとい う従前の定義 (5) と全国調査の結果が異なるものと なっている。この交通は囊胞が大きくなる過程で 膵管に浸食し, 瘦孔を形成するのが原因であると 推定される ${ }^{8)}$ が,この問題を解決するためにはさら なる詳細な病理学的検討が必要である.
病理組織学的には, 厚い線維性組織により構成 される襄胞壁と, 粘液性の高円柱上皮よりなる腫 瘍性上皮を認める ${ }^{9,10)}$. 腫瘍性上皮は種々の異型を 呈し, その異型の程度は low-grade と high-grade の 2 段階に分類され, 従前の cystadenoma, cystadenocarcinoma (non-invasive) に相当する ${ }^{10)}$. Low-grade が若年に, high-grade, 浸潤癌が比較 的高齢に多いことから, MCN は low-grade から high-grade を経て浸潤癌に進行するとみなされ ており,よって low-grade の MCN は前癌病変と 考えられている ${ }^{1)}$.上皮下の血管に富む紡錘形細胞 の増生像が特徵的であり, progesterone receptor (PR) や estrogen receptor (ER) などの免疫組織 学的染色で陽性を示すこの間質は, 卵巣型間質 (ovarian type stroma)，または卵巣様間質 (ovarian like stroma) と呼ばれ, MCN の病理学的診断 において必須と定義されている.

全国調查 ${ }^{2}$ による病理組織異型度の内訳は, 腺腫 129 例 (82.7\%), 非浸潤癌 21 例 (13.4\%), 微小浸 潤癌 4 例 $(2.6 \%)$, 浸潤癌 2 例 (1.3\%) であり, 多 くは良性, あるいは悪性度の低いもので, 浸潤癌 はごく少数であった. 良性例 (mucinous cystade- 

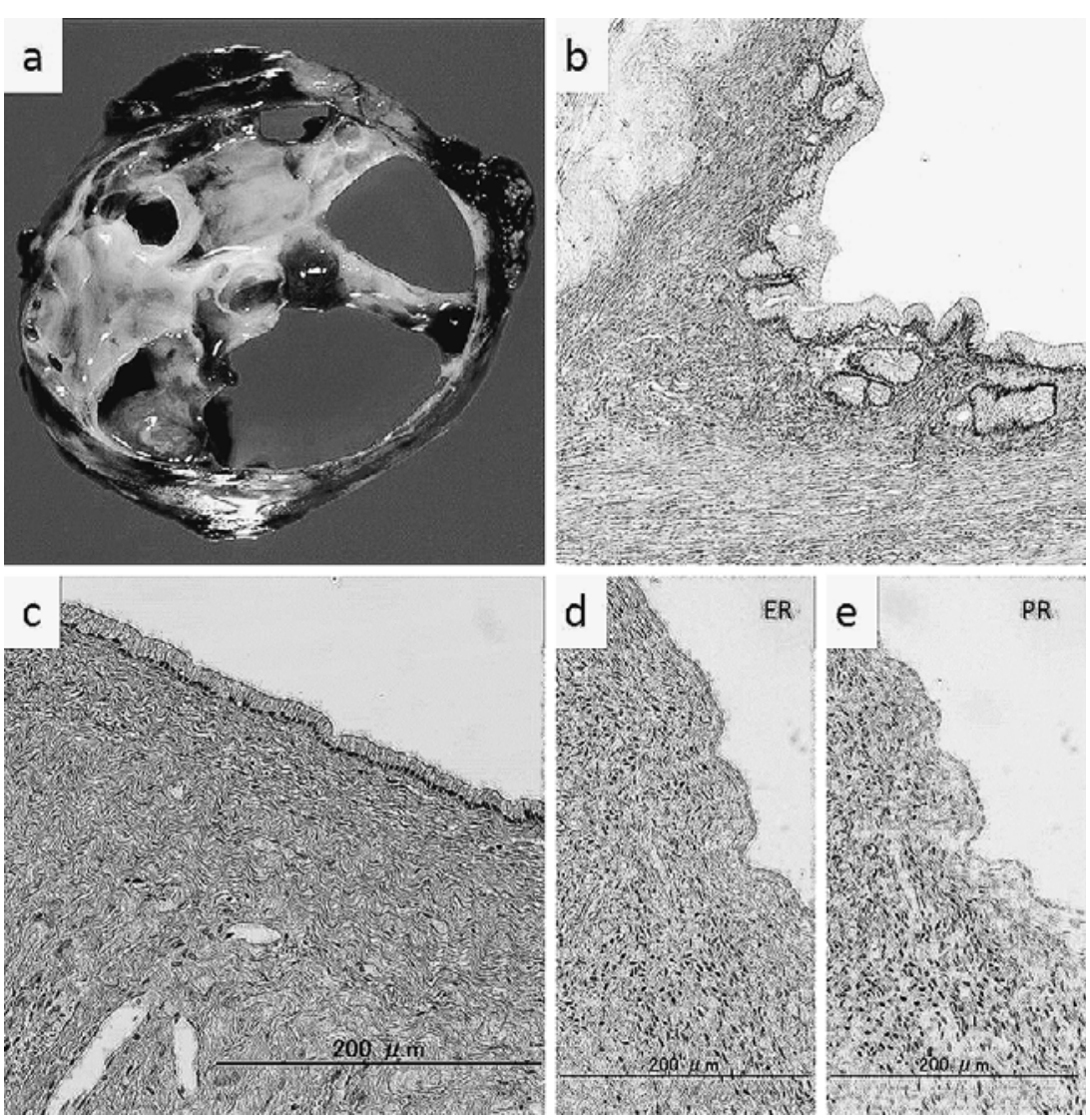

Fig. $1 \mathrm{MCN}$ の肉眼像と病理像

a） MCN の肉眼像：大小の囊胞が共通の被膜に覆われて内腔に凸に存在する（cyst in cyst), 各々の囊胞間には交通を認めない（independent cyst）， あたかも囊胞壁に結節を 思わせる襄胞（mural cyst）が特徵である. b) 種々の異型度を示す粘液性の高円柱上皮 により囊胞内腔が裏打ちされ，上皮下に卵巣型間質を認める。 $\mathrm{c} \sim \mathrm{e})$ 卵巣型間質. 上皮 化に紡鍾形細胞が密に増生しており, 免疫組織化学染色で ER 陽性, PR 陽性を示す (c： HE 染色, d：ER 染色, e : PR 染色).

noma；MCA）と悪性例（mucinous cystadenocarcinoma；MCC)について臨床病理学的因子の比較 で有意な差がみられたものは，囊胞径（MCA： $\mathrm{MCC}=60.1 \pm 38.0 \mathrm{~mm}: 90.0 \pm 45.8 \mathrm{~mm}, \mathrm{p}<$ 0.001）と結節の有無（結節あり症例の割合; $\mathrm{MCA}: \mathrm{MCC}=21.9 \%$ : 51.9\%, $\mathrm{p}=0.003)$ であった. 卵巣型間質における $\mathrm{ER}, \mathrm{PR}$ の陽性率は，検索が なされたものでそれぞれ 78\% (85/109 例)，87.9\% (94/107 例)であり，これらは MCA と MCC の間 に差は認められなかった。

\section{MCN の治療と予後（Table 2)}

MCN は malignant potential を有することより
治療の基本は外科手術であるとされてきた ${ }^{1.7)}$ しし かし，前述したとおり囊胞径の小さい病変や結節 のない病変は腺腫である可能性が高いことから, 2012 年版の IPMN/MCN 国際診療ガイドライ

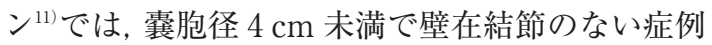
に関しては，高齢者では経過観察も可能であると している.

治療の実際については他稿に譲るが，本稿で紹 介している全国調查 ${ }^{2}$ は外科切除された病変のみ が対象となっており, 前述の通り多くが腺腫で あったことから, 術後 3 年, 5 年, 10 年生存率は 全体で各々 $97.6 \% ， 96.6 \% ， 96.6 \%$ と予後は良好で 
Table 2 MCN の手術成績と予後（全 国調查より）（文献 2 より引 用, 一部改変)

\begin{tabular}{lc}
\hline $\begin{array}{l}\text { 同時性転移 } \\
\text { 肝転移 } \\
\text { 術後再発 }\end{array} \quad 1$ \\
$\quad$ 肝転移 \\
$\quad$ 腹膜播種 \\
転㷌 (死亡, 生存) \\
死因 (原病死, 他病死) \\
原病死例の組織型 \\
$\quad$ 浸潤癌 \\
$\quad$ 非浸潤癌 \\
原病死例の死因 \\
$\quad$ 肝転移 \\
$\quad$ 腹膜播種 \\
\hline
\end{tabular}

ある。しかし，腺腫ではそれぞれ $99.8 \% ， 98.8 \%$, 98.8\%（1 例のみ胃癌による他病死）であるのに対 して, 腺癌では $92.3 \%, 86.5 \%, 86.5 \%$ (腹膜播種 2 例, 肝・肺転移 1 例 $)$ と有意差 $(\mathrm{p}=0.0021)$ を認 めた．腹膜播種のうち 1 例は浸潤癌で, 他の 1 例 は手術時に囊胞液の漏出をきたした非浸潤癌症例 であり, 肝・肺転移による死亡例は浸潤癌であっ た.このことから, 腺腫, 非浸潤癌, 微小浸潤癌 においては, 完全切除がされれば予後は良好であ るといえる。他方, 浸潤癌は 2 例と限られている が, 両症例とも原病死しており, 微小浸潤癌まで の段階で診断し切除を行う必要がある.

\section{MCN の診断}

\section{1. 画像診断 (Fig. 2)}

前述したように, 隔壁を伴った複数の囊胞が比 較的厚い共通の被膜に覆われた, “夏みかん様”の 形態をとることが MCN の肉眼的特徵であり, 典 型例においてはこの特徴が臨床画像上もよく表現 されて所見として現れる.すなわち, 膵体尾部に 発生する, 境界明暸で辺縁整な嚢胞性病変として 描出され, 被膜は線維成分を反映してdynamic CT で遅延性濃染, MRI の T2 強調画像で低信号 を示す。

豪胞間の隔壁は線維性被膜と比較すると薄いこ とが多く，経腹的超音波検査 (ultrasonography； US）やCT では確認できないこともあるが，より
空間分解能の高い超音波内視鏡検査 (endoscopic ultrasonography ; EUS) や組織コントラストの高 いMRI ではほとんどの症例で隔壁が確認できる. 共通の囊胞壁で覆われた囊胞内に, 隔壁によって 境界された襄胞が存在する所見である “cyst in cyst”の構造を確認することで MCN を強く疑う ことができる，単房性襄胞であっても経過観察中 に cyst in cystが出現することもあり，定期的に 画像診断を行うことが肝要である.

“囊胞”であることから, 囊胞内部は US/EUS では低エコー〜無エコー, CT で低吸収, MRIの $\mathrm{T} 1$ 強調像で低信号, T2 強調像で高信号を示すこ とを基本とする。しかし内部に粘液や古い凝血塊 が充満していることから, US や EUS では比較的 エコーレベルの高いデブリ様の内部エコーを認め ることがあり，その場合には CT では水と比較し てやや高吸収を呈し, MRI の T1 強調像で高信号, $\mathrm{T} 2$ 強調像で低信号を示す.多房性囊胞間に交通が ないことから, US/EUS で囊胞腔のエコーレベル に差を生じ, MRIの信号強度が異なるという特徵 (“independent cyst” ${ }^{12)}$ るいは “stained glass appearance” ${ }^{13)}$ ) もある.

$\mathrm{MCN}$ での壁在結節の存在は悪性を疑うもので あり重要な所見の 1 つである。囊胞壁や隔壁から 発生し内腔に向かって突出する充実性病変として とらえられ, 造影 CT や造影超音波で濃染を示す. しかし MCN の場合, 壁在結節にみえて実は壁在 囊胞 $\left(\right.$ mural $\left.\mathrm{cyst}^{8}\right)$ であることも多い. 微小な結節 と囊胞との鑑別には US や CT では難しいことも あり, EUSによる詳細な観察が必要となる。

Zamboni ら ${ }^{5)}$ は MCN を主膵管との交通のない ものと定義し，この所見は MCN と IPMN を鑑別 するのに役立つとされた . しかし, 全国調査でも 示されたように, 主膵管との交通を伴う症例も一 定程度みられることから，主膵管との交通がある ことが必ずしも MCN を否定することにはならな い.これらの交通は MRCP や EUS では描出でき ないことが多く, 全国調査でも術前の内視鏡的逆 行性膵管造影 (endoscopic retrograde pancreatography； ERP）や術後の標本造影でのみ観察で きるものが主であった．膵管造影によって主膵管 との交通が描出された場合でも, MCN は複数の 

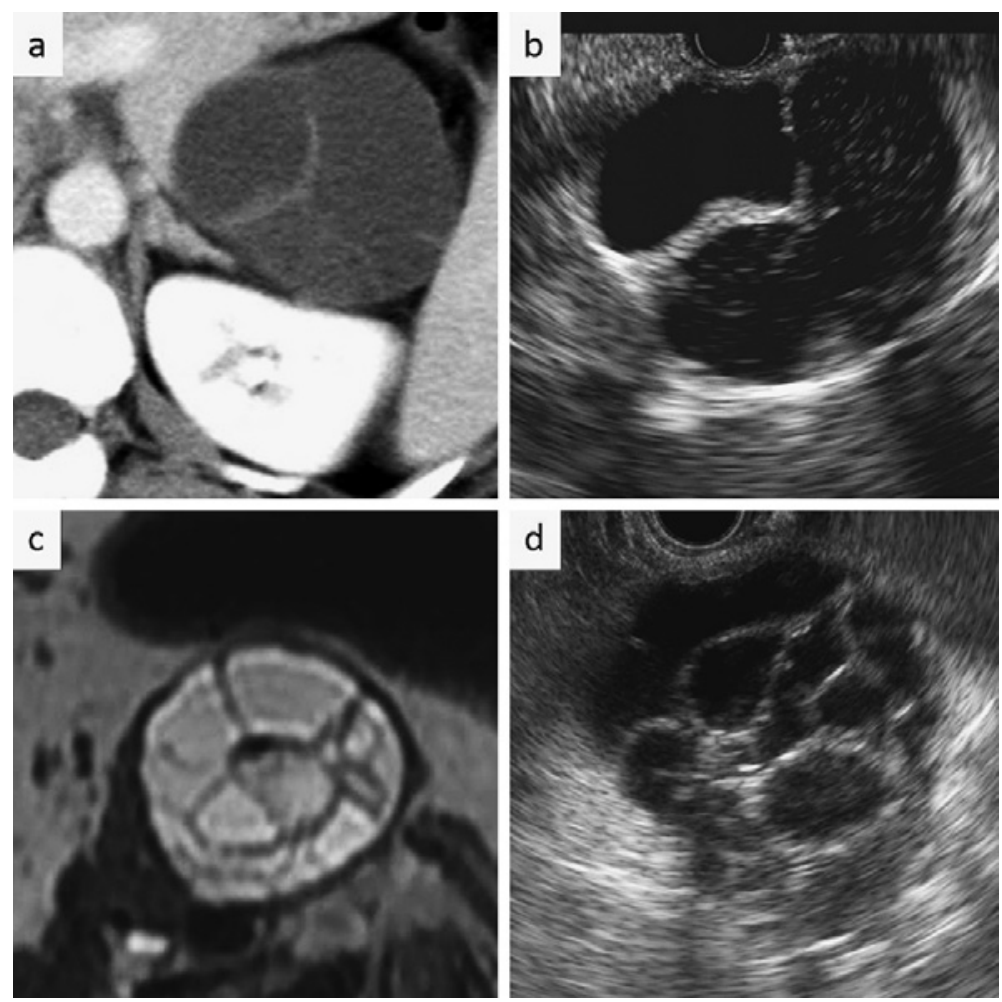

Fig. 2 MCN の画像所見

a, b) 膵尾部に発症した MCN. $50 \mathrm{~mm}$ 大の多房性囊胞性病変である．造影 CT (a) では被膜，隔壁に造影効果を認める. EUS（b）では壁肥厚とともに mural cyst が確認できる. c, d) 膵体部に発症した $40 \mathrm{~mm}$ 大の MCN. MRI の T2 強調像 (c) においては信号強度が異なる複数の震胞が混在している (independent cyst, あ るいは stained glass appearance). EUS（d）でも囊胞内のエコーレベルは震胞 間で差があることがわかる.

囊胞が隔壁を介して独立して存在していることか ら, 造影剤の流入は一部の囊胞のみにみられると いう特徴がある。

\section{2. 襄胞穿刺による襄胞液分析}

典型的な症例に対しては前述したような画像的 特徴によって MCN と診断することは比較的容易 であるが, 非典型的な臨床像・画像所見を示す場 合には後に述べるような他の膵囊胞性病変との鑑 別が困難であることも少なくない. 実際に, 最も 近接して詳細に形態的特徴をとらえることが可能 と思われるEUSをもってしても, 画像診断のみ での正診率は $50.9 \%$ と報告されている ${ }^{14)}$.このた め, 欧米では EUS-FNAによって得られた囊胞液 を分析することで診断の一助とする試みもなされ
ている.

$\mathrm{MCN}$ の震胞液は透明な粘稠性の液体であり， この点において非粘液性囊胞性病変との鑑別とな る。囊胞液を 2 つの指間にとり，指を離して糸を 引く現象を確認すれば粘液といえる。 また, 細胞 診で胞体に粘液を含んだ上皮細胞の有無を確認す ることも重要である。しかし, 囊胞性状と細胞診 による鑑別診断能については, 正診率が 54 ～97\% と報告者によりばらつきがある ${ }^{15)}$.一方, IPMN を含めた粘液性腫瘍の悪性の診断において特異度 は 89〜 100\% と高いものの, 感度は 22〜 100\% で あり ${ }^{15)}$ ，良悪性の鑑別という意味では十分とはい えない。

Frossard $ら^{16)}$ は襄胞液中の CEA の cutoff 值を 
Table $3 \mathrm{MCN}$ の鑑別診断（文献 18 より引用, 一部改変)

\begin{tabular}{|c|c|c|c|c|}
\hline & 隔壁 & 膵管との交通 & 囊胞壁の造影効果 & $\begin{array}{c}\text { 囊胞内の高信号域 } \\
(\mathrm{T} 1 \text { 強調像, 拡散強調像) }\end{array}$ \\
\hline $\mathrm{MCN}$ & $\begin{array}{c}\text { あり } \\
\text { cyst in cyst }\end{array}$ & 時にあり & あり & (粘液, sludge $\stackrel{ \pm}{ \pm}$ debris, 出血) \\
\hline 分枝型 IPMN & $\begin{array}{c}\text { あり } \\
\text { cyst by cyst }\end{array}$ & あり & \pm & $\begin{array}{c}\text { ない場合が多い } \\
\text { (炎症の随伴や粘稠度の高い粘 } \\
\text { 液ではやや高信号) }\end{array}$ \\
\hline $\mathrm{SCN}$ & $\begin{array}{c}\text { あり } \\
\text { microcysts } \\
\text { (honeycomb) }\end{array}$ & なし & $\begin{array}{c}\text { なし } \\
\text { (microcysts 部は } \\
\text { 早期濃染) }\end{array}$ & (稀に macrocyst 内に出血) \\
\hline 非腫瘍性真性囊胞 & \pm & なし & あり & $\begin{array}{c}\text { ある場合が多い } \\
\text { 強い高信号を示すことがある }\end{array}$ \\
\hline 仮性囊胞 & \pm & 時にあり & あり & $\begin{array}{c}\text { ある場合が多い } \\
\text { (sludge / debris, 出血) }\end{array}$ \\
\hline 充実性腫瘍の囊胞変性 & \pm & なし & $\begin{array}{c}\text { あり } \\
\text { (充実部の残存) }\end{array}$ & $\begin{array}{c} \pm \\
\text { (辺縁部が拡散強調像で高信号) }\end{array}$ \\
\hline
\end{tabular}

$400 \mathrm{ng} / \mathrm{ml}, \quad$ CA $19-9$ の cutoff 值を 50,000 U/ml とすることで, $75 \%$ および $81 \%$ の特異度で非粘液 性襄胞と粘液性腫瘍を鑑別できると報告してい る.また, 12 の研究の pooled analysis ${ }^{17}$ では霬胞液 中の CEAの cutoffを $800 \mathrm{ng} / \mathrm{ml}$ とすると感度 $48 \%$, 特異度 $98 \%$, 正診率 $79 \%$ で鑑別可能である としている. 本邦に扔いても, 切除検体から採取 した䨝胞液を中心とした解析で Nagashio $ら^{18}$ が 膵囊胞性病変に対する襄胞液分析の有用性を報告 しており, 囊胞液中 CEA の cutoff を $67.3 \mathrm{ng} / \mathrm{m} l$ として, CA125 (cutoff $10.0 \mathrm{U} / \mathrm{ml}$ ) と組み合わせ ることで, $77.8 \%$ の正診率で MCN と他の襄胞性 病変との鑑別が可能であった. しかし, IPMNに対 する EUS-FNA 後に腹膜播種をきたした報告 ${ }^{19}$ 以降, 本邦では粘液性の襄胞性病変を疑う場合, EUS-FNA は原則禁忌あるいは慎重に行うべき であるとされている。

\section{MCN と鑑別を要する他の膵病変（Table 3)}

MCN の画像診断において鑑別が必要となる他 の膵病変として, MCN 以外の腫瘍性膵豪胞, 非腫 瘍性真性囊胞, 仮性囊胞, 充実性腫瘍の囊胞変性 が挙げられる。

腫瘍性膵囊胞は, MCN, IPMN および漿液性囊 胞腫瘍 (serous cystic neoplasm; SCN) の 3 種類 が大部分を占める。この中で, $\mathrm{MCN}$ との鑑別が問 題となるのは, 分枝型 IPMN と, macrocystic(あ
るいは oligocystic）type の SCN である. 分枝型 IPMN は原則的に主膵管との交通を有するという 点で MCN と鑑別できることが多い. しかし, IPMN でも主膵管との交通が確認できない症例が あり，また MCN でも主膵管との交通が認められ る症例もあることから，この一点のみで鑑別する ことは困難な場合がある. Macrocystic type の $\mathrm{SCN}$ と合わせて, これらの 3 疾患は病変の形態が 重要な鑑別ポイントとなる。すなわち, MCN が “夏みかん様”で厚い被膜に囲まれた cyst in cyst 構造を呈するのに対して, IPMN はブドウの房状 で cyst by cyst の形態をとり, SCN は中心痏痕や 微小霬胞による honeycomb 構造が特徵的であ る. IPMN と SCN はともに共通被膜を持たない点 も MCN との鑑別点となる. また, 微小襄胞が集簇 する oligocystic type の SCN では dynamic CT で 早期相から強く濃染されることも他の 2 疾患とは 異なる点として重要である.

非腫瘍性真性襄胞にはリンパ上皮襄胞（lymphoepithelial cyst; LEC), 類上皮囊胞 (epidermoid cyst), 皮様霬胞 (dermoid cyst) がある。こ れらは, 内部にケラチン, 高濃度のたんぱく質を 含むことから, CT で囊胞内にあたかも微細な内 部構造があるようにみえることがあり, MRIの $\mathrm{T} 1$ 強調像，拡散強調像で高信号を認める。

仮性囊胞は急性膵炎のエピソード後に生じた震 胞であれば $\mathrm{MCN}$ との鑑別に迷うことはない。し 
かし，膵炎，外傷等のエピソードがないものでは 鑑別に苦慮する。囊胞内のデブリや出血は仮性囊 胞, MCNのいずれにおいても認められる所見で ある. 血液検査における炎症反応の有無や, 継時 的変化の有無, 場合によっては EUS-FNA で採取 した囊胞液の性状や囊胞液中のアミラーゼ值を用 いて鑑別を行うこともある.

腫瘍内出血や広範な壊死により囊胞変性をきた す充実性腫瘍として, solid pseudopapillary neoplasm (SPN), 神経内分泌腫瘍 (neuroendocrine tumor; NET), 腺房細胞癌 (acinar cell carcinoma；ACC)などが挙げられる。これらの疾患は いずれも, 本質的には充実性腫瘍であることから, 壊死と混在した充実部分が同定されることが多 く, 充実部分の形態や造影効果から MCN と鑑別 を行う. SPNの場合は充実部分が造影早期には不 明瞭であっても, 門脈相から平衡相にかけて遅延 性の濃染パターンを示すのが特徴である ${ }^{20)}$. 一方, NET P ACC では比較的早期から充実部分が濃 染されることが多く, EUS-FNA で充実部分を穿 刺して, 組織学的に診断することも可能である.

$$
\text { おわりに }
$$

膵 $\mathrm{MCN}$ の臨床・病理学的特徵について, 全国 調査の結果とともに概説し, 画像診断において重 要と思われる事項を述べた. MCN は比較的稀で はあるが, 臨床・病理学的に特徵を有した腫瘍で あり, 治療適応や非典型例の対応など, 今後も検 討すべき点が残されている。

\section{文献}

1) Compagno J, Oertel JE. Mucinous cystic neoplasms of the pancreas with overt and latent malignancy (cystadenocarcinoma and cystadenoma). A clinicopathologic study of 41 cases. Am J Clin Pathol 1978; 69: 573-80.

2) Yamao K, Yanagisawa A, Takahashi K, et al. Clinicopathological features and prognosis of mucinous cystic neoplasm with ovarian type stroma A multi-institutional study of the japan pancreas society. Pancreas 2011; 40: 67-71.

3）山雄健次, 柳沢昭夫, 高橋邦幸, 他. 卵巣型間質を伴 う MCN の臨床病理学的特徵と予後一日本膵臟学会多 施設共同研究から一. 膵臟 $2012 ; 27: 9-16$.

4) Suzuki A, Atomi Y, Sugiyama M, et al. Cystic neo- plasm of the pancreas; A Japanese multiinstitutional study of intraductal papillary mucinous tumor and mucinous cystic tumor. Pancreas 2004; 28: 241-6.

5) Zamboni G, Scarpa A, Bognia G, et al. Mucinous cystic tumors of the pancreas: Clinicopathological features, prognosis and relationship to other mucinous cystic tumors. Am J Surg Pathol 1999; 23: 410-22.

6) 木村 理. Mucinous Cystic Neoplasms (MCN) の手術 適応は変わったか. 肝胆膵 $2013 ; 67: 733-7$.

7) Yamao K, Nakamura T, Suzuki T, et al. Endoscopic diagnosis and staging of mucinous cystic neoplasms and intraductal papillary-mucinous tumors. J Hepatobiliary Pnacreat Surg 2003; 10: 142-6.

8) Solcia E, Capella C, Kloppel G, et al. Tumor of the pancreas. Atlas of tumor pathology. Series III, fascicle 20. Washington DC: Armed Forces Institute of Pathology, 1997.

9）福嶋敬宜. Mucinous Cystic Neoplasm 悪性例の病理 像㧍よび頻度. 肝胆膵 $2011 ； 63: 731-5$.

10）古川 徹. 膵臓癌の前癌病変. 日消誌 $2015 ; 112$ ： 1457-63.

11) Tanaka M, Fernandez-del Castillo C, Adsay V, et al. International consensus guidelines 2012 for the management of IPMN and MCN of the pancreas. Pancreatology 2012; 12: 183-97.

12）岡庭伸司, 岩下和広. 膵囊胞性病変の肉眼像と超音波 診断 <中上級 >. Jpn J Med Ultrasonics 2017；44： $235-44$.

13）石上康生, 西江昭弘, 浅山良樹, 他. 膵粘液性囊胞腫 瘍. 画像診断 $2013 ; 33: 912-26$.

14) Brugge WR, Lewandrowski $K$, Lee-Lewandrowski $E$, et al. Diagnosis of pancreatic cystic neoplasms: a report of the cooperative cyst study. Gastroenterology 2004; 126: 1330-6.

15) Lim LG, Itoi T, Lim WC, et al. Current status on the diagnosis and management of pancreatic cysts in the Asia-Pacific resion: role of endoscopic ultrasound. J Gastroenterol Hepatol 2011; 26: 1702-8.

16) Frossard JL, Amouyal P, Amouyal G, et al. Performance of endosonography-guied fine needle aspiration and biopsy in the diagnosis of pancreatic cystic lesions. Am J Gastroenterol 2003; 98: 1516-24.

17) Van der Waaij LA, van Dullemen HM, Porte RJ. Cyst fluid analysis in the differential diagnosis of pancreatic cystic lesions: a pooled analysis. Gastrointest Endosc 2005; 62: 383-9.

18) Nagashio $Y$, Hijioka S, Mizuno $N$, et al. Combination of cyst fluid CEA and CA125 is an accurate diagnostic tool for differentiating mucinous cystic neoplasms from intraductal papillary mucinous neoplasms. Pancreatology 2014; 14: 503-9.

19) Hirooka Y, Goto H, Ito A, et al. Case of intraductal papillary mucinous tumor in which endosonographyguided fine needle aspiration biopsy caused dissemination. J Gastroenterol Hepatol 2003; 18: 1323-4. 
20）片桐真理，村上康二，尾島英知，他．襄胞壁，囊胞液 性状からみた膵囊胞性疾患の画像診断. 胆と膵 $2015 ; 36: 1331-7$.

\title{
Pancreatic mucinous cystic neoplasm: diagnosis
}

\author{
Shin HaBA, Kenji YamaO, Takahiro ToYama, Akihito IIDA, \\ Naoto MizoguCHI, Nobuto OotAnI ${ }^{1)}$, Hirozumi SAWAI'), Yuka KIRIYAMA ${ }^{3)}$, \\ Makoto NARITA $^{1)}$, and Kazuo HARA ${ }^{4)}$
}

Key words: Pancreatic mucinous cystic neoplasm (MCN), Nation-wide observational study of MCN, Imaging diagnosis, Cyst fluid analysis

Pancreatic mucinous cystic neoplasms are cystic lesions which appear commonly in the pancreatic body and tail in middle-aged females, and have a characteristic macroscopic description referred to as "orange like shape", or "cyst in cyst". In 2007, a multi-institutional retrospective observational study of MCN with ovarian type stroma was conducted by the Japan Pancreatic Society. Clinicopathological features and long-term prognosis were described based on 156 collected MCN cases in this study. For the diagnosis of MCN, capturing the characteristic clinical and pathological features using imaging modalities such as US, CT, MRI, and EUS is necessary. Cyst fluid analyses were also considered for difficult cases. Although diagnosing typical MCN is relatively easy, care should be taken when diagnosing atypical cases.

1) Department of Gastroenterology, Narita Memorial Hospital (Aichi)

2) Department of Surgery, Narita Memorial Hospital (Aichi)

3) Department of Pathology, Narita Memorial Hospital (Aichi)

4) Department of Gastroenterology, Aichi Cancer Center Hospital (Aichi) 